\title{
高温領域における不純物添加ポリエチレン の絶縁破壊
}

$\begin{array}{lllll}\text { 名古屋大学 } & \text { 宮 } & \text { 圭 } & \text { 一 } \\ \text { 名古屋大学 } & \text { 沢 } & \text { 五 } \\ \text { 名古嫏大学 } & \text { 家 } & \text { 田 } & \text { 正 } & \text { 之 }\end{array}$

\section{1. まえがき}

合成高分子工業の発達は電気絶縁性能のすぐれた材 料の開発を促進し，笔力部鹏に扣いて泉，乙れら高分 子物質が高電王電気絶縁材料として果たす役割は高く 評価されている。

高電压プラスチック電力ケーブルのように，その絶 縁厚が大きい場合には，一般にその絶緣破壊は卜リ一 状形式をとることが知られている。このトリ一状破買 の発生の原因上して，固体諗電体中あるいはそれと導 体との界面に存在するボイド，あるいは異物などが指 摘されている。その防止対策しして，電王安定剤と称 する潦加物を混入する試み加活発に絤討されている。 実用上のある程度の目的は逆成されているものの，そ れらの基礎亡なる破罗機棈に関してはじゅうぶ明ら 加とはいえない現状にある。

一方，代表的な高分子であるポリエチレンの破塄機 構を基本的に理解するために，比較的薄いフィルム状 試料あるいは凹形式料䘮用いて多くの研究がなされて きた。その結果，種々の現象か明らかにされ，破壊機 構についても種々の考察加加えられている。

天川吅 ${ }^{(1)}$ は直流破罗值とパルス破壊值との関係を 空間電荷効果加ら解播し，てれらに関し Cooper 氏ら あ種々検討を加えている。(2) 高温では電気機械破堎説 を支持するという報告むるる。(3) 最近，宮内民ら ${ }^{(4)}$ は 室温領域におけるポリエチレンの總縁破壊機構とし

Dielectric Breakdown of Impurity Doped Polyethylene in the High Temperature Region. By K. MIYAIRI, Member, G. SAWA, Member \& M. IEDA, Member (Department of Electrical Engineering, Nagoya University).

容入圭一：正圆，名古展大学工学部雪気工学科助手

讯 五郎：正虽，名古屋大学工学部雷気工学科期教授

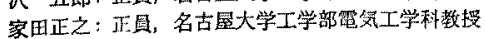

\section{論 文

て，Fröhlich 氏の電子荆破壊理諭に移動度の活性化 過程を考慮に入れた機構を提唱している。

筆者らは，従来よりポリエチレンに不純物を潦加す

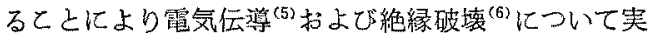
験的，理論的な検討を加え，不純物怔電気䋓縁特性に 大きな影響を与えるととをすでに報告した。前報 ${ }^{(6)}$ は，液体空素温度付近を中心已した低温頜域*におけ る絶縁枝壊について論じたが，それに引き紸き室温付 近を中心とした高温領域*においてポリエチレンの絶 縁破罗に与える不純物效果を調べた結果，従来の報告 にみられない顕著な効果が得られたので報告する。さ らに本報では，破耍の前駆電流の摹電特性に関する特 性值を絶緣破䏅特性の面加ら推定するという新しい試 みを行ない，をの結果を高電界導電電流の測定から得 られた結果と比較した。

\section{2. 実験 結 果}

試料，電極系および印加電生電源は前報(6) と同じで あるが,ここでは試料についてのみ再で簡単に述心る。 低密度ポリエチレンをべースレジンとし，てれに2 種 類の添加剂; パイレンおよび带電防止剂(AS-1) をそ れぞ扎添加した 2 種類の試料於よび無添加(ブランク) の試料以ついて夹験を行なった。芇電防止刜 AS-1は ブリードアウトが少なく，ポリエチレンとの相溶性が 良いといわれている。(7) しれらベースポリエチレンお 上び添加剂の物理的性質を第 1 表に示す。

前報 ${ }^{(6)}$ に報告したように，低温領域の場合と買なり

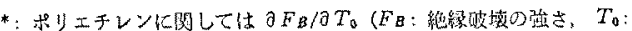

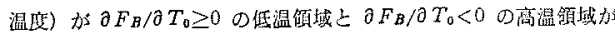
存在するととが多くの研究者に上り指摘点机ているのて，ことて

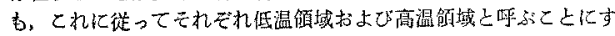
な。 


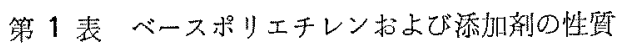
Table 1. Properties of base polyethylene and additives.

\begin{tabular}{|c|c|c|c|}
\hline $\begin{array}{l}\text { ベース } \\
\text { vシン }\end{array}$ & 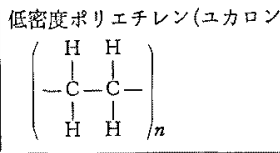 & $\begin{array}{l}\text { EH } 30) \\
\text { 密 度 } \\
\text { メルトインデックス }\end{array}$ & $2^{0.919 \mathrm{~g} / \mathrm{cc}}$ \\
\hline \multirow{2}{*}{ 添拁涼 } & パイレン $\left(\mathrm{C}_{16} \mathrm{H}_{10}\right)$ & 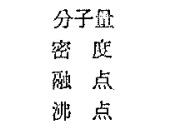 & $\begin{array}{l}202 \\
1.277 \mathrm{~g} / \mathrm{cc} \\
149^{\circ} \mathrm{C} \\
404^{\circ} \mathrm{C}\end{array}$ \\
\hline & 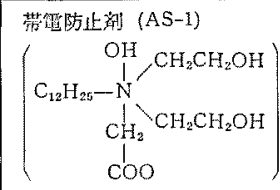 & 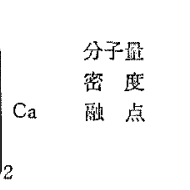 & $\begin{array}{l}736 \\
0.943 \mathrm{~g} / \mathrm{cc} \\
0 \sim 5{ }^{\circ} \mathrm{C}\end{array}$ \\
\hline
\end{tabular}

高溫領域においてはパイレン添加ポリエチレンの破壞 值は䓡㮇加ポリエチレンのそれと大きな差を示してい ないが，带電防止郕を添加したものは大きな相違を示 している。したかっって，本報告では主として，この大 きな差を示した AS-1 港加ポリエチレンの結果を中心 に述べる。

$\langle 2 \cdot 1\rangle$ 絶縁破壊の強さの温度依存性および添加量依 存性第1図にブランクポリエチレンおよび帯電防 止剂 1 重量パーセント (1 wt \%) 添加ポリエチレン の絶縁破罗の强さの温度依存性走す。 $-40^{\circ} \mathrm{C} \sim 100$ ${ }^{\circ} \mathrm{C}$ の温度領域では,パイレン添加ポリエチレンはブラ ンクポリエチレンの結果と大きな差がない。 $-75^{\circ} \mathrm{C}$ 癿近以上の温度では帯蟹防止剂添加系扎上びブランク ポリエチレンいず机ついても，パルス $(5 \mu \mathrm{s}, 10 \mathrm{~Hz})$ 破壊值怙よび直流破壊值はともに $\left(\partial F_{B} / \partial T_{0}\right)<0\left(F_{B}\right.$ ： 絶縁破壊の強さ，To：温度）のいわ石高温領域の絶 縁破壊特性を示している。 $-75 \sim-40^{\circ} \mathrm{C}$ 付近の低温

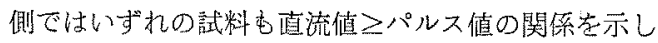
ているが，約 $-40^{\circ} \mathrm{C}$ 以上の高温側では带電防止剂添 加ポリエチレンの直流值がパルス值より低い值を示し ている。以下，直流破壊值の著しい低下走す带電防 止剂添加系ポリエチレンについて，さらに検討を加え る。ブランクポリエチレンに比べ，破壦値の低下の著 しい $0{ }^{\circ} \mathrm{C}$ に打いて破罗值の添加量への依存性を調へ た結果牚 2 図に示す。この結果加ら，印加特間の長

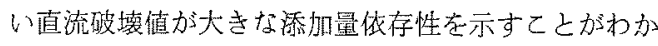
る。また，薄電電流も带電防止剂 AS-1 の添加量とと

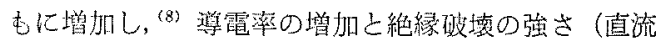
值）の低下には相関があると考えられる。パイレン添 加ポリチレンではこのような依存性宗さず，不純

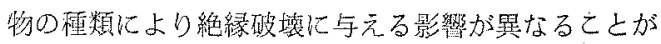

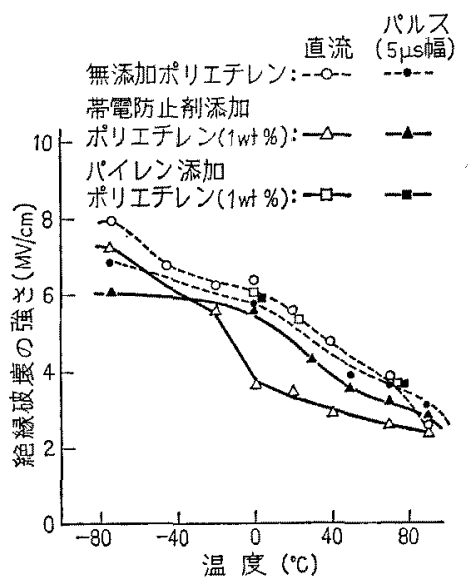

第 1 図絶縁破壊の強さの温度依存性

Fig. 1. Temperature dependence of electric strength of polyethylene with and without. additives.

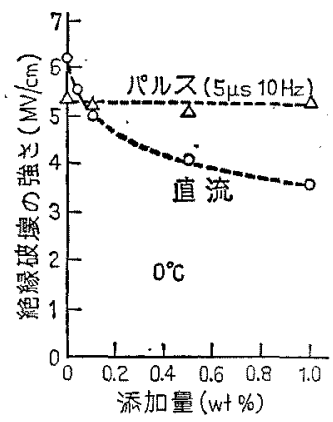

第 2 図 絶縁破壊の強さと添加量との関係 Fig. 2. Relation between electric strength and concentration of antistatic agent.

明らかになっだ。これは前報の低温領域での不純物效 果と対照的な効果であり，これらの事夷から委低温領 域上高温頜域ではこの䋓緑破壊を支配している過程が 異なることがわかる。

$\langle 2 \cdot 2\rangle$ 絶縁破壊の時間依存性温度の上昇と之 手に破壊值が低下する現象が何に支配されているかに よって種々の破壞機棈が提示されている。(9) 破壞值の 時間依存性は支配的な機構を推定するうえの重要な情 報である。第 3 図は $0{ }^{\circ} \mathrm{C}$ 亿招いて帯電防止剂添加系 ポリエチレンの破壊值が卯加電圧のパルス幅に依存 し，パルス幅の增加とともに減少することを示してい る。Fröhlich 氏の笔子熱破塄理論( ${ }^{(9)}$ では破境值に時 間传存性が現われるのは $10^{-6} \mathrm{~s}$ 以下(10)または $10^{-10} \mathrm{~s}$

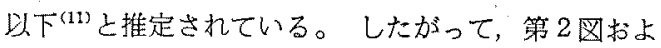
び第 3 図の結果から，添加量が多くパルス幅の大きい 場合の支配的な絶縁破㯖機構として，まず純熱破壊が 


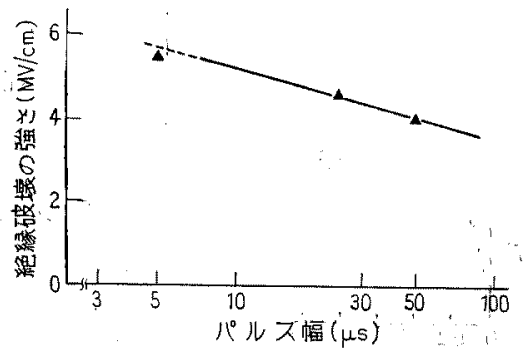

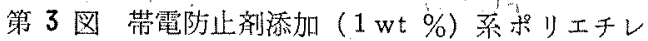
ンの絶縁皮壊強さと印加電圧パルス幅との関保

Fig. 3. Electric strength of the polyethylene doped with antistatic agent ( $1 \mathrm{wt} \%)$ as a function of pulse width of applied voltage.

考えられる。

〈2.3〉厚さ依存性上記の諸結果加ら純熱破藵 譏構を考えるとき，熱伝導度们関係した放熱効果の破 壊值への寄与について調べることが奏験結果の解析に あたって有効である。後述の（1）式上りわかるよう に，乙の放熟效果が無視できないときは破墩值の厚さ 依存性が現われるはずである。実测されれた破塄值は第

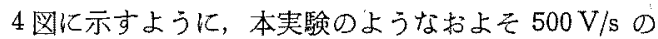
上昇速度を有する電在印加（直流破壊）に対しては央 測された破壊值には厚さ依存性がみられない。したが って，直流破壊時間より短い時間，た之えげ $\mu \mathrm{s} \sim \mathrm{ms}$ 程度の方形波パルス電圧の上きには，なおさら熱妘導 の寄与は無視できるものと考えら机る。

\section{3. 実験結果の検討}

まず，不純物添加ポリエチレンについての絶縁破壊 特性に検討を加え，その結果をもとにブランクポリエ チレンの絶縁破壊について若干述べる。

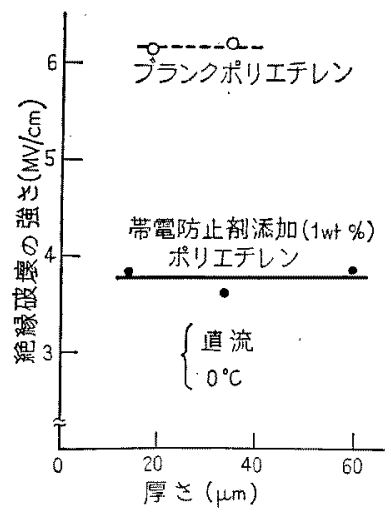

第 4 図直流破壊值の厚さ依存性

Fig. 4. Thickness dependence of DC electric strength.
带電防止剂添加系ポリエチレンの絶緣破壊について

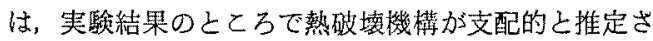
れることを述べた。熱破罣理論は電気伝導との関係に より展開されている。したがって，逆に絶縁破壊特性 加ら電気伝導特性の推定も可能であり，以下にその理 論式を導出し，そ机によって絶縁破壊特性加ら導いた 電気伝導に関する特性値を導き，高電界に枋ける薄電 電流の測定結果加ら導加扎た手のと比較するという新 しい試みを行なう。

（1）理論式の導出一般任熱破塄の基本式は次 式で表わされる。

$$
C_{v} \frac{d T}{d t}-\operatorname{div}(\kappa \operatorname{grad} T)=\sigma F^{2}
$$

ここで, $C_{v}$ : 体積比熱, $T:$ 温度， $t$ : 封間，

$\kappa$ : 熱伝導度, $\sigma$ : 䄈電率, $F$. 電界

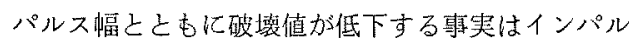
又熱破壊の可能性を示㖟するとともに，架間電荷效果 すなわち空聞電荷がキャリアの翰总を妨げ，破填値を 上沓させるという效果を否定するものと解釉される。 これより，空間電荷制限電流を考虑の対象外飞するこ 上ができるとすれば，(1)式の右扨は厚さによって変 化しないものとすることができる。

前述の上うに破壊值は愿さ俄存性を示していないの で

$$
\left|C_{v} \frac{d T}{d t}\right| \gg|-\operatorname{div}(\kappa \operatorname{grad} T)|
$$

が成立する屯のと考元られ，結局，次式の上うに

$$
C_{v} \frac{d T}{d t}=\sigma F^{2}
$$

いわゆるインパルス熱破壊の式となる。

ところで，導電率 $\sigma は$ は実測仁よる高電界で大きな 電界依存性を示している。(12) したがって，ここでは電 流密度 $(j=\sigma F)$ 加試料厚さ依存性示さず，温度上 昇とともに增加し，バルクの状態によって制限される ような高電界電気伝導機構として次の二つの過程を考 える。

$$
\begin{aligned}
& \text { (i) } j=\sigma F=j_{0} \exp \left(-\frac{\phi-F_{e} \lambda_{i}}{k_{0} T_{0}}\right) \ldots \ldots \text { (4) } \\
& \text { (ii) } \sigma=\sigma_{0} \exp \left(-\frac{\phi-\beta \sqrt{F}}{k_{0} T_{0}}\right) \ldots \ldots \ldots \ldots \text { (5) } \\
& \text { ここで, } \lambda_{i}: \text { 跳躍距離, } k_{0} \text { : ボルッマン定数, } \\
& \phi: \text { 活性化エネルギー, } T_{0} \text { : 温度, } j_{0}, \sigma_{0}, \beta \text { : } \\
& \text { 定数 }
\end{aligned}
$$

(4)式はイオン伝導古るいは電子のホッピング伝導, また（5)式は Poole-Frenkel 效果による電気伝酻に 対する高電界における近似式として知ら机ている。 
以下，これらの式をもとに絶緑破壤と電気伝導との関 係について検討する。〔ただし，(6)〜(12) 式の導出 は付録参照了

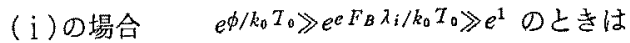
（4）式を（3）式に代入し，皘分を行なった後で整理 すると，方北波パルス電圧に対し次式が近似式として 得られる。

$$
F_{B} \tau e^{\frac{F_{B} e \lambda_{i}}{k_{0} T_{0}}} \simeq \frac{a C_{\nu} T_{0} e \lambda_{i}}{\phi j_{0} f} e^{\frac{\phi}{k_{0} T_{0}}}
$$

ここで, $\tau$ : パルス愊, $f:$ くり返し周波数,

$a:$ 電界上㤡速度

一定の上昇率で增加する直流電圧に対しては，（6） 式に求いて $f \tau=1$ とする。また, 直流值の温度低存 性は次式のようになる。

$$
\frac{\Delta F_{B} / F_{B}}{\Delta T_{0} / T_{0}} \simeq \frac{\phi-F_{B} e \lambda_{i}}{F_{B} e \lambda_{i}}
$$

（ii）の場合 $\quad e^{\phi / k_{0} T_{0}} \gg e^{\beta \sqrt{F_{B}} / k_{0}} T_{0} \gg e^{1}$ のとき(5) 式を（3）式代代入し，（i）の場合と同様に次式が得 られる。方形波パルス電压に対して

$$
F_{B} \tau e^{\frac{\beta \sqrt{F_{B}}}{k_{0} T_{0}}} \simeq \frac{a C_{v} \beta^{2}}{2 f \sigma_{0} \phi k_{0}} e^{\frac{\phi}{k_{0} T_{0}}} f\left(\frac{\beta \sqrt{F_{B}}}{k_{0} T_{0}}\right)
$$
ただし

$$
f(x)=\frac{x^{4}}{\sum_{r=0}^{5}(-1)^{r} \frac{5 ! x^{5-r}}{(5-r) !}+120 e^{-x}}, x=\frac{\beta V \overline{F_{B}}}{k_{0} T_{0}}
$$

通常, $(8)$ 式の $F_{B}$ の变化比よる右辺の变化は $T_{0}$ が一定ならば小さいので，

$$
F_{B} \tau e^{\frac{\beta \sqrt{F_{B}}}{k_{0} T_{0}}} \simeq \text { const }
$$

とするととができる。直流值に対して岵 $f \tau=1$ とす る。(10) 式において $F_{B}$ を $T_{0}$ で微分すると，直流 值の温度依存性として次式が得ら机る。

$$
\frac{\phi}{k_{0} T_{0}}+4 \simeq(1+\gamma)\left[1-\frac{\Delta F_{B} / F_{B}}{\Delta T_{0} / T_{0}}\right] x
$$

ただし

$$
\gamma=\frac{5 x^{3}-20 x^{2}+60 x-120}{x^{4}-5 x^{3}+20 x^{2}-60 x+120}, \quad x=\frac{\beta \sqrt{F_{B}}}{k_{0} T_{0}}
$$

（2）電気伝導過程を支配する物性基礎量の推定と 絶縁破壤機構従来よりポリエチレンの電気伝導現 象については種々検討さ机ているものの，その伝導機 構に関してはまだじゅうぶれ解明されていない点が多 い。帯電防止剂添加ポリエチレンについての導電特性 に関する実測結果に执いても，第5 図 (a)，(b)に 示すように前述の（4）式拈上び（5）式のいずれの
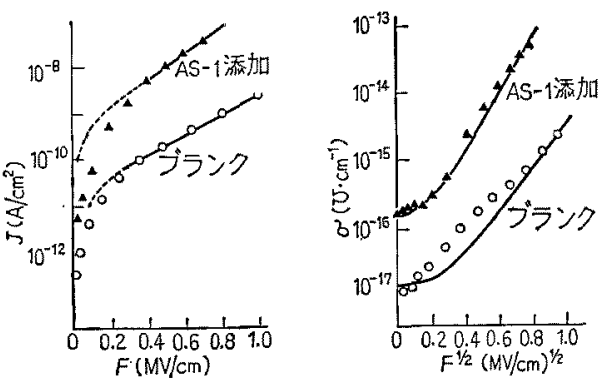

第 5 図 帯電防止剂 AS-1 添加ポリエチレンの 高電界導電特性 ${ }^{(17)}$

Fig. 5. High field conduction of AS-1 doped polyethylene.

形にも近似的に表わすととができ，導電電流の電界依 存性だけからでは，いずれの機構が支配的であるか 断定し難い状態である。ここでは，帯電防止剤 AS-1 1 wt \% 添加ポリエチレンの絶縁破壊特性加ら推定 される電気伝盲と実測された電気伝遒特性 ${ }^{(12)}$ を比较 し，支配的な伝導機構の检討を試みる。

温度 $\left(T_{0}\right)$ 一定のもとにおいて $F_{B}-\log \tau$ の関係 (第3図)に（6）式あるいは（10）式を適用す机ば, 近似的に $\lambda_{i}$ あるいは $\beta$ 加推定される。また，直流 值の温度依存性（第1图）に(7) 式古るいは (11) 式花組合せると $0 \sim 75^{\circ} \mathrm{C}$ の領域で $\phi$ が推定される。 そして，さらに $C_{v}{ }^{(14)}$ を使って破買の絶対值上り残り の未知数 $j_{0}$ または $\sigma_{0}$ が求められる。以上の方法に より得られた結果を第 2 表任示した。ただし， $j$ およ び $\sigma$ は $T_{0}=75^{\circ} \mathrm{C}, F=1 \mathrm{MV} / \mathrm{cm}$ における值である。 また，パルス破壊値より得られたパラメータ $\left(\lambda_{i}, \beta\right)$ を使って直流值を理論的に求めることもできる。(4) 式を用いた場合には $0^{\circ} \mathrm{C} に て F_{B} \sim 0.05 \mathrm{MV} / \mathrm{cm}$, (5) 式を用いたときは $F_{B} \sim 1 \mathrm{MV} / \mathrm{cm}$ が得られる。実測值 $3.5 \mathrm{MV} / \mathrm{cm}$ に比へていずれす低い值を示しているが,

\begin{tabular}{|c|c|c|}
\hline & 緦緣酸壊より & 雪気伍㼛丈り \\
\hline 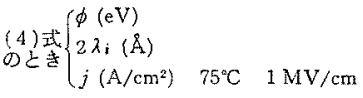 & $\begin{array}{c}0.1 \\
2.5 \\
2.6 \times 10^{-10}\end{array}$ & $\begin{array}{l}1.2 \\
40 \\
10^{-6} \sim 10^{-7}\end{array}$ \\
\hline (5)式 $\left\{\begin{array}{l}\phi(\mathrm{eV}) \\
\beta(\mathrm{eV} / \sqrt{\mathrm{MV} / \mathrm{cm})} \\
\sigma\left(\frac{1}{0 . \mathrm{cm}}\right) 75^{\circ} \mathrm{C} \quad 1 \mathrm{MV} / \mathrm{cm}\end{array}\right.$ & $\begin{array}{l}1.2 \\
0.124 \\
3 \times 10^{-10}\end{array}$ & $\begin{array}{c}1.2 \\
0.3 \\
10^{-12} \sim 10^{-13}\end{array}$ \\
\hline
\end{tabular}
（5）式の場合のほうが近い值を示している。これら は，いずれも導電電流の测定結果と完全な一致は示し ていないが, Poole-Frenkel 効果化よる電気伝導機構 を考えた場合のほうか電気伝導と絶縁破壊とから得ら

第 2 表 $\phi, \lambda_{i}, \beta, \sigma, i$ の値

Table 2. Values of $\phi, \lambda, \beta, \sigma$ and $i$. 
れる基碟量が近い值安示している。

これらの多少の相遈のでる原因などについて今後さ らに恰討を要するか， 以上の結果からみる上 PooleFrenkel 効果による電気伝導過程と，それに基つくく インパルス熱破壊機構を考えれば帯䉓防止剤添加ポリ エチレンの0〜75 $\mathrm{C}$ の温度頜域における絶縁破壊が定 量的にも理解されるのではないか己考えられる。

無添加ポリエチレンの絶縁破壊機棈についてはまだ じゅうぶん明らかでなく，ここでは従来報告された結 果之筆者らの結果を総合して，その機構を解鄱すると きの問題点をあげるにとどめる。前報 ${ }^{(6)} に$ 怙いてポリ エチレンの低温頜域（主に液体穻素温度領域）の絶縁 破壊特性老子なだれ皮壊形式上り检討を加えた。 高温領域における実験結果は従来より報告されている が，破壊機構については見解が統一されておらず不明 確な点加多い。最近，宮内氏ら ${ }^{(4)}$ は室温付近の破流特 性を Fröhlich 氏の電子熱皮猿理墖の変容に上り解釈 を試みている。前述のように，不純物学添加するなど して尊電率を壃加させると熱破壊形式になるものと考 えられるが，導電率の小さいブランクポリエチレンで は前述の場合亡破壊特性が異なっており, 別の過程が 破壊を支配していることがうかがわれる。第 1 図に示 したように室温什近以下では，天川氏ら (1)の報告にむ

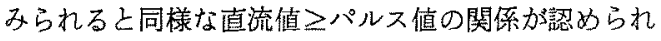
る。筆者らは前報 ${ }^{(15)}$ で室温におりる值流值とパルス 值の厚さ依存性を報告したが，パルス值には若干の愿 さ依存性を認めることができる。Cooper 氏ら(16) あこ

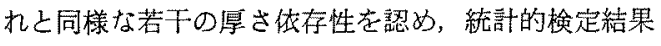
からむ有意であると述べている。これらの諸效果を考 えると純熱破燷，Fröhlich氏の電子熱破罱など現在広 く知られている理覦のみでは説明しがたい。

\section{4. むすび}

高温領域のポリエチレンの絶縁破啰を不純物添加効 果によって检討し，添加剤の效果は低温領域と著しく 異なることを見いだした。特に一種の界面活性剤であ る帯電防止剂添加ポリエチレンの絶縁破壊特性は，1 ンパルス熱破壊の理諭によって説明さ扎るととを示し た。また，渻電特性を破壊特性から検討し，高電界に おける導電特性の奏測結果と比較した。すなるち，破 壊特性加ら導電特性についての基礎的諸量を導く新し い試みを行なった。無添加系ポリエチレンの絶縁破垻 譏構はいぜん未解決の点が残されたが，従来までに報 告された諸結果および筆者らの夷験結果をるとに， そ の解釈上の問題点を指摘した。

ここで採用した帯電防止戍はある種の電王安定剤と
類仪しており，実用プラスチック絶縁設計の基礎焟料 として役だてば幸いである。

終わりに，陚料作成に関してで協力いただいた三菱 泊化株式会社樹指研究所 墨田，板食雨氏，ならびに 日ごろご指導いただく籣原卯吉名古屋大学名栄教授に 厚く感謝します。本研究の一部は文部省科学研究費の 援助によって行なわれた。

(昭和 47 年 3 月 29 日受付, 同 47 年 7 月 27 日再受付)

\section{文献}

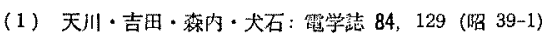

(2) A. Bradwell \& R. Cooper: Proc. Instn Elect. Engrs 118, 247 (1971)

(3) K.H. Stark \& C. G. Garton: Nature 178, 1225 (1955)

(4) 宮内·矢作: 管気学会譣文誌 92-A，36 (昭 47-1)

（5）家田・沢・森田・箱原：筑学誌 88，1349（沼 43-7)

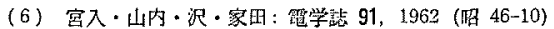

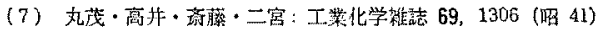

（8）北川 - 沢 - 家田：昭 45 䉓気四学会柬海支部速大 $19 \mathrm{a}-\mathrm{D}-4$

(9) J. J. O'Dwyer: The Theory of Dielectric Breakdown of Solids (1964) Oxford Univ, Press, London

(10) J.H. Simpson: Proc. Phys. Soc. A 63, 86 (1950)

(11) H. Frơhlich \& J. J. O'Dwyer: Proc. Phys. Soc. A 63, $81(1950)$

（12）拓藤・沢・家田：昭 45 笛気四学会束海装部連大 $19 a-D-5$

(13) 家田・沢: 電学臸 89, 812 (吸 44-5)

(14) B. Wunderlich: J. Polymer Sci. Pt. C, 41 (1963)

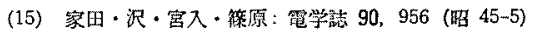

(16) R. Cooper, C. H. Rawson \& D. W. Watson: Nature 19?, 663 (1963)

(17) R. Cooper, R. M. Higgin \& W. A. Smith: Proc, Phys. Soc. 76,817 (1960)

\section{付 録}

(6) （12) 式の導出

(I) イオン伝導あるいはホッピング伝導のとき 〔(4)式の場合〕（4）式老（3）式代入すると $C_{v} d T=F j_{0} e^{-\phi / k_{0} T} e^{F e \lambda_{i} / k_{0} T} f \tau d t$ (付 1) また電界は

$$
F=a t
$$

である加ら

$$
\left.C_{v} d T=F j_{0} e^{-\phi / k_{0} T} e^{F e \lambda_{i} / k_{0} T} f \tau \frac{d F}{a} \text { (付 } 1^{\prime}\right)
$$

ここで, $e^{F e \lambda_{i} / k_{0} T}$ は $e^{\phi / k_{0}} T$ に比べて温度に詨して 変化が小さいとし，次式のように近似する。

$$
\int_{T_{0}}^{T_{m}} e^{\phi / k_{0} T} d T \simeq \frac{j_{0} f \tau}{a C_{v}} \int_{0}^{F_{B}} F e^{\frac{F e \lambda_{i}}{k_{0} T_{0}}} d F \quad \text { (付 3) }
$$

左辺を $\int_{T_{0}}^{T_{m}} e^{\phi / k_{0} T} d T \simeq \frac{k_{0} T_{0}^{2}}{\phi} e^{\phi / k_{0} T_{0}}$ と近似すれば(17)

$$
\begin{aligned}
\frac{k_{0} T_{0}^{2}}{\phi} & \exp \left(\frac{\phi}{k_{0} T_{0}}\right) \simeq\left(\frac{j_{0} f \tau}{a C_{v}}\right) \frac{k_{0} T_{0}}{e \lambda_{i}} \\
& \times\left[e^{\frac{F_{B} e \lambda_{i}}{k_{0} T_{0}}}\left(F_{B}-\frac{k_{0} T_{0}}{e \lambda_{i}}\right)-\left(0-\frac{k_{0} T_{0}}{e \lambda_{i}}\right)\right]
\end{aligned}
$$




$$
\simeq \frac{j_{0} f \tau k_{0} T_{0}}{a C_{v} e \lambda_{i}} e^{\frac{F_{B} e \lambda_{i}}{k_{0} T_{0}}} F_{B}
$$

となり, 結辟,

$$
F_{B} \tau e^{\frac{F_{B} e \lambda_{i}}{k_{0} T_{0}}} \simeq \frac{a C_{v} e \lambda_{i} T_{0}}{\phi j_{0} f} e^{\frac{\phi}{k_{0} T_{0}}}
$$

これが本文の（6）式である。

次に（付 4) 式江て $f \tau=1$ と扔き, $F_{B} e \lambda_{i} \gg k_{0} T_{0}$ 考虑すると

$$
F_{B} \simeq \frac{a C_{v} e \lambda_{i} T_{0}}{\phi j_{0}} \exp \left(\frac{\phi-e \lambda_{i} F_{B}}{k_{0} T_{0}}\right) \ldots(\text { 付 } 6)
$$

ことで $F_{B}$ を $T_{0}$ について锺分し, $F_{B} e \lambda_{i} \gg k_{0} T_{0}$, $\frac{\phi-e F_{B} \lambda_{i}}{k_{0} T_{0}} \gg 1$ を考虑しながら変形すると

$$
\frac{T_{0}}{F_{B}} \frac{d F_{B}}{d T_{0}}=-\frac{\phi-e F_{B} \lambda_{i}}{e F_{B} \lambda_{i}}
$$

が得られる。したがって

$$
\frac{\Delta F_{B} / F_{B}}{\Delta T_{0} / T_{0}} \simeq-\frac{\phi-e F_{B} \lambda_{i}}{e F_{B} \lambda_{i}}
$$

となる。

(II) Poole-Frenkel 効果による電気伝導のとき ((5)式の場合)（5)式老（3)式化代入し付録 （Ｉ）の場合之同様任近似すると

$$
\int_{T_{0}}^{T_{m}} e^{\phi / k_{0} T} d T \simeq \frac{\sigma_{0} f \tau}{a C_{v}} \int_{0}^{F_{B}} F^{2} e^{\frac{\beta \sqrt{F}}{k_{0} T_{0}}} d F \text { (付 } 8 \text { ) }
$$

肪得られる。(付 8 )式の左辺の積分は付録〔I〕の場 合上同様汇

$$
\int_{T_{0}}^{T_{m}} e^{\phi / k_{0} T_{0}} d T \simeq \frac{k_{0} T_{0}^{2}}{\phi} e^{\phi / k_{0} T_{0}}
$$

と近似する。右辺は $\beta V \bar{F} / k_{0} T_{0}=u$ とおくと $d F=\frac{\left(k_{0} T_{0}\right)^{2}}{\beta^{2}} 2 u d u$ 加ら,

$$
\int_{0}^{F_{B}} F^{2} \exp \left(\frac{\beta V \bar{F}}{k_{0} T_{0}}\right) d F=2\left(\frac{k_{0} T_{0}}{\beta}\right) \int_{0}^{\frac{\beta \sqrt{F_{B}}}{k_{0} T_{0}}} u^{5} e^{u} d u
$$

となる。ところで

$$
\int_{0}^{u} u^{5} e^{u} d u=e^{u} \sum_{r=0}^{5}(-1)^{r} \frac{5 ! u^{5-\tau}}{(5-r) !}
$$

であるから，結局，(付 8)式は次式のようになる。

$$
\begin{aligned}
& F_{B}{ }^{2} \tau \exp \left(\frac{\beta V \overline{F_{B}}}{k_{0} T_{0}}\right) \simeq \frac{a C_{\nu} \beta^{2}}{2 f \sigma_{0} \phi k_{0}} \\
& \times\left\{\frac{\left(\frac{\beta V \overline{F_{B}}}{k_{0} T_{0}}\right)^{4}}{\sum_{r=0}^{5}(-1)^{r} \frac{5 !\left(\frac{\beta V \overline{F_{B}}}{k_{0} T_{0}}\right)^{5-\tau}}{(5-r) !}+120 e^{-\frac{\beta \sqrt{F_{B}}}{k_{0} T_{0}}}}\right\} \\
& \quad \times \exp \left(\frac{\phi}{k_{0} T_{0}}\right)
\end{aligned}
$$

$$
\simeq \frac{a C_{\nu} \beta^{2}}{2 f \sigma_{0} \phi k_{0}} \exp \left(\frac{\phi}{k_{0} T_{0}}\right) f\left(\frac{\beta V \overline{F_{B}}}{k_{0} T_{0}}\right)
$$

ここで

$$
f(x)=\frac{x^{4}}{\sum_{r=0}^{5}(-1)^{r} \frac{5 ! x^{5-r}}{(5-r) !}+120 e^{-x}}
$$

この（付 9 ) が本文の（8）式である。

直流電圧による絶緑破境のときは $f \tau=1$ と报くと

$$
\begin{aligned}
& \sigma_{0} \exp \left(-\frac{\phi-\beta V \overline{F_{B}}}{k_{0} T_{0}}\right) \\
& \simeq \frac{\frac{a C_{0} \beta^{6}}{2 \phi k_{0}\left(k_{0} T_{0}\right)^{4}} \frac{2 k_{0} T_{0}}{\phi}}{5 !\left(\frac{\beta \sqrt{F_{B}}}{k_{0} T_{0}}\right)^{5-r}}+120 e^{-\frac{\beta \sqrt{F_{B}}}{k_{0} T_{0}}}
\end{aligned}
$$

とこで, $F_{B}$ を $T_{0}$ について微分すると

$$
\frac{\frac{d F_{B}}{d T_{0}}}{\frac{F_{B}}{T_{0}}} \simeq \frac{\frac{\phi-\beta \sqrt{F_{B}}+4 k_{0} T_{0}}{k_{0} T_{0}}}{\left(\frac{\beta \sqrt{F_{B}}}{k_{0} T_{0}}\right)} *
$$

$\left.* \frac{-\left(\frac{e^{\frac{\beta \sqrt{k_{0}} T_{0}}{k_{0}}} \sum_{r=0}^{4}(-1)^{r} \frac{5 !}{(5-r) !}\left(\frac{\beta V \overline{F_{B}}}{k_{0} T_{0}}\right)^{4-r}-120}{\left.e^{\frac{\beta \sqrt{F_{B}}}{k_{0} T_{0}}} \sum_{r=0}^{5}(-1)^{r} \frac{5 !}{(5-r) !}\left(\frac{\beta \sqrt{F_{B}}}{k_{0} T_{0}}\right)^{5-r}+120\right)}\right)}{\left\{1+\left(\frac{\left.e^{\frac{\beta \sqrt{F_{0}} T_{0}}{k_{0}}} \sum_{r=0}^{4}(-1)^{r} \frac{5 !}{(4-r) !}\left(\frac{\beta \sqrt{F_{B}}}{k_{0} T_{0}}\right)^{4-r}-120\right)}{e^{\frac{\beta \sqrt{F_{B}}}{k_{0} T_{0}}} \sum_{r=0}^{5}(-1)^{r} \frac{5 !}{(5-r) !}\left(\frac{\beta V \overline{F_{B}}}{k_{0} T_{0}}\right)^{5-r}+120}\right)\right\}},\right\}$

$$
*\left(\frac{\beta \sqrt{F_{B}}}{k_{0} T_{0}}\right)
$$

$x=\frac{\beta \sqrt{F_{B}}}{k_{0} T_{0}}$ とし，右辺の〔ノを $\gamma$ とおくと

$$
\begin{aligned}
& \frac{\phi}{k_{0} T_{0}}+4 \simeq(1+\gamma)\left[1-\frac{d F_{B}}{d T_{0}} / \frac{F_{B}}{T_{0}}\right] \frac{\beta V \bar{F}_{B}}{k_{0} T_{0}} \\
\therefore & \frac{\phi}{k_{0} T_{0}}+4 \simeq(1+\gamma)\left[1-\frac{\Delta F_{B} / F_{B}}{\Delta T_{0} / T_{0}}\right] x \text { (付12) }
\end{aligned}
$$

まだ

$$
\begin{aligned}
\gamma & =\frac{e^{x}\left(5 x^{4}-20 x^{3}+60 x^{2}-120 x+120\right)-120}{e^{x}\left(x^{5}-5 x^{4}+20 x^{3}-60 x^{2}+120 x-120\right)+120} \\
& \simeq \frac{5 x^{3}-20 x^{2}+60 x-120}{x^{4}-5 x^{3}+20 x^{2}-60 x+120}(\because x \sim 10)
\end{aligned}
$$

との（付 12）式が本文（11）式である。 